\title{
A case-control study on the association of hepatitis $B$ virus infection and hepatocellular carcinoma in Northeast Brazil*
}

\author{
Estudo caso-controle da associação entre a infecção por vírus $B$ da \\ hepatite e carcinoma hepatocelular em uma área no nordeste brasileiro
}

\begin{abstract}
Helma Cotrim ${ }^{\star \star}$, Eduardo Mota*, Livia Leite**, Luciana Silva**, Luiz Lyra
COTRIM, $H$. et al. A case-control study on the association of hepatitis $B$ virus infection and hepatocellular carcinoma in Northeast Brazil. Rev. Saúde públ., S.Paulo, 26: 301-5, 1992. Hepatitis B virus (HBV) serological markers were investigated in 40 incident cases of hepatocellular carcinoma (HCC) and in two age and sex matched control groups, comprising 40 patients with other cancers and 80 healthy individuals, resident in Bahia, Brazil. Serologic tests were done by radioimmunoassay. The study observed high proportion of seropositivity to HBsAg (42.5\%) and of those presenting HBsAg or antiHBc (65.0\%) among HCC cases, higher in men than women and in those aged 17 to 30 years old. HBsAg seropositivity among HCC patients was greater than in the control group with other cancers $(7.5 \%)$ and in healthy controls (2.5\%), corresponding to odds ratio estimates of 15.0 (95\% CI 3.29,68.30) and 33.0 (95\% CI $9.13,119.28$ ), both statistically significant. $\mathrm{HBeAg}$ was not observed and antiHBe was present in $41.2 \%$ of cases, suggesting the absence of viral replication, possibly with viral DNA intergration into the hepatocyte genome. The presence of cirrhosis was associated with $\mathrm{HBsAg}$ seropositivity among HCC cases. A history of chronic alcoholism is shown to be more frequently related to those cases with cirrhosis. This study highlights the relevant association between $\mathrm{HCC}$ and HBV in Northeast Brazil, particularly for young individuals, and the high risk of development of $\mathrm{HCC}$ for $\mathrm{HBsAg}$ carriers.
\end{abstract}

Keywords: Hepatitis B, complications. Hepatoma, complications. Risk factors. Liver neoplasms, complications.

\section{Introduction}

Hepatocellular carcinoma is one of the ten leading neoplasms worldwide. It is estimated that nearly one million new cases are registered every year, most of them in African and Asian countries ${ }^{4}$. Various studies have described a concurrent distribution of HCC incidence and the endemic level of the hepatitis B surface antigen (HBsAg). The adult population of China and other Asian countries are believed to have HBsAg seropositivity rates of up to 10 to $15 \%$ and incidence rates of HCC varying from 10 to 20 cases per

* Part of a thesis presented to the Medical School of the Federal University of Bahia for the obtaining of a doctoral degree in medicine, 1988. Partially supported by CNPq ("Conselho Nacional de Desenvolvimento Científico e Tecnológico"), Brazil.

** Medical School, Federal University of Bahia, Brazil

*** Medical Doctor

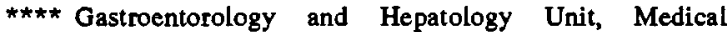
School, Federal University of Bahia, Brazil

Reprints: H. Cotrim - Laboratório de Pesquisas em Gastroenterologia e Hepatologia - Hospital Universitário Prof. Edgard Santos - $6^{9}$ andar -Sala 1105 -Rua Augusto Viana, $s / n^{2}$ - Canela - 40110-060 - Salvador, BA - Brasil
100,000 inhabitants per year. In contrast, in areas where less than $1 \%$ of the population are $\mathrm{HBsAg}$ carriers, $\mathrm{HCC}$ incidence rates of one to five cases per 100,000 inhabitants are observed ${ }^{17}$.

Published data in Brazil, gathered through histopathological information have reported 1,849 cases of liver cancer, representing $0.5 \%$ of the total number of patients with neoplasms registered from 1976 to $1980^{3}$. Some $59.3 \%$ were males and $51.2 \%$ classified as HCC. This source shows only $42 \mathrm{HCC}$ cases from the state of Bahia during the same period, which is heavily underrepresented. Previous surveys carried out in the city of Salvador, Bahia, revealed prevalence rates of $4.2 \%$ of HBsAg ${ }^{5}$ and $30.0 \%$ of hepatitis B antibody surface antigen (antiHBs) among blood donors 9 . However, controlled studies for the estimation of the frequency of $\mathrm{HBsAg}$ carriers according to the risk of development of hepatocellular carcinoma are not yet available in Brazil.

The present study was conducted for the purpose of evaluating the magnitude of 
the association between HBV infection and $\mathrm{HCC}$, and the relative importance of some risk factors, in Salvador, Bahia, Brazil.

\section{Methods}

This age and sex matched case-control study was carried out in Salvador, a city located in the coastal area of Northeast Brazil. Incident cases of hepatocarcinoma included those referred by some city hospitals and physicians during the period 1982-1987. A total of 40 patients were studied. Participation criteria included histologic confirmation of HCC through blind percutaneous biopsy, laparoscopic biopsy or autopsy. History of alcoholism was recorded in all cases, and chronic alcoholism defined as the regular ingestion of alcoholic beverages over eight or more years and a mean daily consumption level of 80 or more grams of ethanol.

Two control groups were defined. One was formed of 40 individuals, chosen from among patients newly admitted to city hospitals who presented other primary neoplasms, with normal levels of hepatic biochemical parameters, and the other of 80 healthy individuals, presenting normal transaminase levels (Reitmam-Frankel method), selected from among individuals attending private clinics for periodic examinations as part of job requirements. Participation criteria included the absence of history of blood transfusion, jaundice and hepatitis. Homosexuals, health professionals and those referring the usage of intravenous drugs were excluded.

Participants of all three groups had blood samples collected by venipuncture using disposable materials and serological determination of HBV markers. HCC cases had exams for $\mathrm{HBsAg}$, antiHBs, antibody to hepatitis $B$ to core antigen (antiHBc), hepatitis $\mathrm{B}$ and antigen $(\mathrm{HBeAg})$ and antibody to hepatitis $B$ and antigen (antiHBe), and controls had exams for HBsAg, antiHBs and antiHBc. All serological tests for HBV markers were performed by radioimmunoassay using Abbott kits (North Chigago, USA).

The presence of $\mathrm{HBsAg}$ and $\mathrm{HBcAg}$ in samples of liver tissues was also detected in 26 cases of HCC using the immunoperoxidase technique.
Table 1. Frequency of hepatitis B virus (HBV) serological markers in 40 cases of hepatocellular carcinoma and control groups of cancer patients (40) and healthy subjects $(80)$.

\begin{tabular}{lrrrrrr}
\hline HBV & \multicolumn{2}{c}{ Cases } & \multicolumn{2}{c}{$\begin{array}{c}\text { Cancer } \\
\text { controls }\end{array}$} & \multicolumn{2}{c}{$\begin{array}{l}\text { Healthy } \\
\text { controls } \\
\text { serological }\end{array}$} \\
markers & $n$ & $\%$ & $n$ & $\%$ & $n$ & $\%$ \\
\hline HBsAg & 17 & 42.5 & 3 & 7.5 & 2 & 2.5 \\
antiHBc & 9 & 22.5 & 2 & 5.0 & 5 & 6.3 \\
HBsAg or & & & & & & \\
antiHBc & 26 & 65.0 & 5 & 12.5 & 7 & 8.8 \\
antiHBs* & 2 & 8.7 & 11 & 29.7 & 17 & 21.8 \\
HBeAg** & 0 & - & - & - & - & - \\
antiHBe* & 7 & 41.2 & - &. & - & - \\
\hline
\end{tabular}

- Percentages calculated for HBsAg negatives.

* Tested for 17 HCC HBsAg positives.

The samples were examined for histological findings using standard procedures.

\section{Results}

Overall proportion of HBsAg seropositivity in the group of cases of hepatocellular carcinoma was $42.5 \%$ (Table 1). In this group cumulative percentages of HBV serological markers were $65.0 \%$ for those presenting $\mathrm{HBsAg}$ or antiHBc. The absence of $\mathrm{HBeAg}$ positivity in contrast to an antiHBe positivity rate of $41.2 \%$ was observed.

The evaluation of HBV markers in samples of liver tissue demonstrated that out of $26 \mathrm{HCC}$ cases examined $19.2 \%$ were positive for $\mathrm{HBsAg}$, all of them showing also HBsAg seropositivity. Only one case had liver tissue positive for $\mathrm{HBcAg}$.

The mean age of $\mathrm{HCC}$ patients was $49.3 \pm 15.3$, varying from 17 to 82 years. Table 2 shows that cases were found more often in the age group 51 years and older. The 17 to 30 year-old age group presented the highest frequency of seropositivity to

Table 2. Age distribution of seropositivity to hepatitis $B$ virus serological markers in 40 cases of hepatocel. lular carcinoma.

\begin{tabular}{lccc}
\hline $\begin{array}{l}\text { Age } \\
\text { (years) }\end{array}$ & $\begin{array}{c}\text { Number } \\
\text { observed }\end{array}$ & $\begin{array}{c}\mathrm{HBsAg} \\
\text { positivity } \\
\%\end{array}$ & $\begin{array}{c}\mathrm{HBsAg} \text { or antiHBc } \\
\text { positivity } \\
\%\end{array}$ \\
\hline 17.30 & 6 & 66.7 & 83.3 \\
31.50 & 13 & 38.5 & 53.8 \\
$51+$ & 21 & 38.1 & 66.7 \\
\hline Total & 40 & 42.5 & 65.0 \\
\hline
\end{tabular}


Table 3. Odds ratio (OR) estimates and confidence intervals (CI) of hepatocellular carcinoma comparing cases to cancer controls and healthy controls.

\begin{tabular}{lrrrrrrr}
\hline Cases & \multicolumn{3}{c}{ Cancer controls } & \multicolumn{3}{c}{ Healthy controls } \\
& OR & \multicolumn{2}{c}{$95 \%$ Cl } & \multicolumn{2}{c}{ OR } & $95 \% \mathrm{Cl}$ \\
\hline Overall & 15.0 & 3.29, & 68.30 & $33.0^{* *}$ & 9.13, & 119.28 \\
Males & 10.6 & 2.05, & 54.96 & 93.5 & 5.20, & - \\
Females & 7.0 & 0.70, & 69.49 & 7.0 & 1.17, & 42.0 \\
Age < 30 & 23.4 & 0.89, & 613.02 & 45.0 & 1.80, & - \\
Age 31-50 & 3.4 & 0.53, & 22.43 & 7.5 & 1.21, & 46.51 \\
Age 51+ & 12.3 & 1.37, & 110.31 & 53.5 & $2.90,989.54$ \\
\hline
\end{tabular}

Sex and age strata: independent comparisons.

- $X^{2}(1$ d.f. $)=12.25 ; p=0.000465$ (Mantel-Haenszel Matched Chi-square Test)

** $X^{2}$ (1 d.f.) $=28.44 ; p<0.00001$ (Mantel-Haenszel Matched Chi-square Test)

HBsAg. Some 25 (62.5\%) cases were male. HBsAg was present in $48.0 \%$ of males and in $33.3 \%$ of female patients, a difference not statistically significant. Among cancer controls, seropositivity was found to be $8.0 \%(2 / 25)$ and $6.7 \%(1 / 15)$ for men and women, respectively, and for healthy controls the only two HBsAg positives were women.

The comparison of the frequency of HBV serological markers as between HCC cases and controls showed that cases had a proportion of HBsAg seropositivity nearly six times greater than the cancer controls and 17 times greater than healthy controls. Odds ratio estimates for $\mathrm{HBsAg}$ positivity were $15.0(95 \%$ CI $3.29,68.30)$ as compared to cancer controls and 33.0 (95\% CI $9.13,119.28$ ) When compared to healthy controls, both of them statistically significant (Table 3). Moreover, the risk of HCC for those who were exposed (HBsAg positives) was higher for males than females, and also for individuals aged less than 30 years old and for those 51 years and over.

Cirrhosis (histologic diagnosis) was present in $30.0 \%(12 / 40)$ of HCC cases. Some $75.0 \%(9 / 12)$ of cases showing cirthosis were $\mathrm{HBsAg}$ seropositive in contrast to $28.6 \%(8 / 28)$ of $\mathrm{HBsAg}$ seropositivity among those not showing cirrhosis, a statistically significant difference $\left(\mathrm{X}^{2}=7.410 ; \mathrm{p}=0.006\right)$.

Chronic alcoholism was registered in $42.5 \%$ (17/40) of HCC cases, and was not significantly associated to $\mathrm{HBsAg}$ seropositivity or cirrhosis. In fact, the proportion of HBsAg positivity among cases who referred chronic alcoholism was $41.2 \%$ (7/17) and for those who did not refer it was $43.5 \%$ (10/23). Moreover, seven out of 12 cases with cirrhosis $(58.3 \%)$ presented chronic alcoholism in contrast to 10 out of 28 cases $(35.7 \%)$ without cirrhosis $\left(\mathrm{X}^{2}=1.759 ; \mathrm{p}=0.185\right)$. In addition, HBsAg seropositivity was related to cirrhosis in the presence of chronic alcoholism: 71.4\% (5/7) of $\mathrm{HBsAg}$ positivity for cases showing cirthosis in contrast to $20.0 \%(2 / 10)$ for those without cirrhosis (Fisher's Exact Test= 0.0584). Among HCC cases without chronic alcoholism 80.0\% (4/5) with cirrhosis tested positive to HBsAg while only $33.3 \%(6 / 18)$ of those without cirthosis presented a positive test to HBsAg (Fischer's Exact Test $=0.0886$ ).

\section{Discussion}

The overall proportion of seropositivity to HBsAg among cases of hepatocellular carcinoma observed in this study was comparable to one described in Japan, but lower than those from hyperendemic areas of Asia and Africa ${ }^{8,10,15}$. Sakuma et al. ${ }^{12}$ observed in Japan a relative risk of HCC for seropositives of 29.4 while in New York City the risk was of $9.7^{11}$, lower than that described by Beasley et al. ${ }^{2}$ in Taiwan, an area of high endemicity, where a relative risk of 233 of $\mathrm{HCC}$ development was found. In the group studied a significant estimate of risk was observed although differences in methods should be allowed for in comparing findings related to the magnitude of the association between HBV and HCC. Moreover, the present study suggests that under comparable exposure conditions HCC cases presented a higher frequency of seropositivity to HBV markers 
than did controls with other cancers, indicating the relative specificity of this association.

Although strongly associated with the presence of $\mathrm{HBsAg}$, the overall proportion of $30.0 \%$ of cirrhosis is much lower than reported frequencies of $60 \%$ to $80 \% 7,13,18$. This may be due to the fact that histological diagnosis followed percutaneous liver biopsies in the majority of cases. In addition, the macroscopic findings on laparoscopy or autopsy, this latter performed in only three cases, were not taken into consideration.

The role of chronic alcoholism was only evaluated among cases. However, the data indicated that a history of alcoholism was more frequently related to $\mathrm{HCC}$ cases with cirrhosis than to those without it, and that the HBsAg association with cirrhosis was found among those reporting alcoholism.

It is noteworthy that few (8.7\%) HCC patients were seropositive to antiHBs, in contrast to $29.7 \%$ for cancer controls and to $21.8 \%$ for healthy controls. Schafritz et al. ${ }^{13}$ demonstrated DNA-HBV integration to hepatic cells in antiHBs positive $\mathrm{HCC}$ patients detected by a recombinan-DNA technique. It suggests that even in the presence of antiHBs, liver carcinoma could be related to HBV infection. Among HCC patients, however, only two aged 61 and 82 years old, had antiHBs in serum without other HBV markers, perhaps indicating the role of other etiologies. It seems likely that young $\mathrm{HBsAg}$ carriers present a higher risk of $\mathrm{HCC}$, possibly acquiring the infection early in life through vertical transmission, as has already been observed in the population studied ${ }^{14}$. It might also be speculated that male individuals are more susceptible to infection and to the development of liver disease.

Positivity to $\mathrm{HBeAg}$ was not observed. Seropositivity to antiHBe in this study may indicate the absence of viral replication and possible integration of viral DNA to the liver cell genome ${ }^{6,13}$. More recent studies have suggested that possitivity to antiHBe in HBsAg carriers may represent a new viral strain due to mutation in its pre-core region, affecting $\mathrm{HBeAg}$ synthesis ${ }^{1,16}$. However, in order to test this hypothesis it would be necessary to identify other serological markers of viral replication and to conduct studies in molecular biology. In this study, the observation of antiHBe in serum with nearly absent $\mathrm{HBcAg}$ in liver tissue suggests that carcinogenesis was initiated following viral integration to hepatic cells.

The results presented make it clear that the HBsAg carrier state is an important risk factor of hepatocellular carcinoma in Northeast Brazil.

COTRIM, H. et al. Estudo caso-controle da associação entre a infecção por vírus $B$ da hepatite e carcinoma hepatocelular em uma área no nordeste brasileiro. Rev. Saúde públ., S. Paulo, 26: 301-5, 1992. Estudou-se a associação entre carcinoma hepatocelular (CHC) e a infecção pelo vírus $B$ da hepatite (VHB) em Salvador, Bahia (Brasil), utilizando-se o desenho caso-controle, pareado por idade e sexo, comparandose a frequêencia de positividade aos marcadores virais de um grupo de 40 casos de CHC com dois grupos controles: 40 individuos com outras neoplasias e 80 indivíduos sadios. Utilizou-se a técnica de radioimunoensaio para os testes sorológicos. Foram observadas altas proporções de indivíduos positivos para AgHBs $(42,5 \%)$ e daqueles com AgHBs ou antiHBs $(65,0 \%)$ entre os casos de CHC. A proporção de positivos para AgHBs entre os casos foi maior do que no grupo controle com outras neoplasias $(7,5 \%)$ e no grupo de indivíduos sadios $(2,5 \%)$, equivalente a estimativas de risco de 15,0 (Intervalo de Confiança (IC) a $95 \%$ de $3,29,68,30$ ) e de 33,0 (IC a $95 \%$ de $9,13,119,28$ ), ambos estatisticamente significantes. Não foi observada positividade ao AgHBe AntiHBe estava presente em $41,2 \%$ dos casos, sugerindo a ausência de replicação viral, com integração do DNA do vírus ao genoma hepático. Entre os casos de CHC houve associação entre cirrose e AgHBs. Foi referida história de alcoolismo crónico mais frequentemente por aqueles com cirrose. $O$ estudo demonstra a relevante associação entre CHC e VHB, principalmente em indivíduos jovens.

Descritores: Hepatite B, complicaçōes. Hepatoma, complicações. Fatores de risco. Neoplasias hepáticas, complicações.

\section{Referências Bibliográficas}

1. AKALANE, Y.; YAMANAKA, T.; SUZUKI, H.; SUGAI, Y.; TSUDA, P.; YOTSUMOTO, S.; OME, S.; OKAMOTO, H.; MIYAKAWA, Y.; MAYUME, M. Chronic active hepatitis with hepatitis $B$ vinus and antibody against and antigen in the serum. Gastroenterology, 99: 1113-9, 1990.

2. BEASLEY, R.P.; HWANG, L.Y.; LIN, C.C.; CHIEN, C.S. Hepatocellular carcinoma and hepatitis B virus. Lancet, 2: 1129-33, 1981.

3. BRUMINI, R., ed. et al. Cancer no Brasil: dados histopatológicos 1976-1980. Brasília, Ministério da Saúde, 1982.

4. DI BISCEGLIE, A.M. Hepatocellular carcinoma. Ann. intern. Med, 108: 390-401, 1988. 
5. GOMF ;, L.S. Estudo clínico e histológico de pr .tadores assintomáticos do antígeno de superfície do vírus B (AgHBs) e seu anticorpo (antiHBs) em Salvador, Bahia, 1979. [Tese de Mestrado Faculdade de Medicina da UFBA].

6. HARRISON, T.J.; CHEN, J.Y.; ZUCKERMAN, A.J. Hepatitis $B$ virus and hepatocellular carcinoma. In: Zuckerman, AJ. ed, Clinics in tropical medicine and communicable diseases. Philadelphia, WB Saunders, 1986. p. 395-402.

7. JOHNSON, PJ. \& WILLIAMS, R. Cirmosis and etiology of hepatocellular carcinoma. J. Hepatol., 4: 140-7, 1987.

8. LONDON, W.T. Primary hepatocellular carcinoma: etiology, pathogenesis and prevention. Hum. Pathol., 12: $1085-97,1981$.

9. LYRA, L.G.; DAMASCENO, A.P.; COTRIM, H.P.; MOTA, E; SILVA, L. Prevalence of antibody to hepatitis $B$ virus in an urban population of Northeast Brazil. Rev. Inst. Med trop., S.Paulo, 28: 406-9, 1986.

10. OKUDA, H. Primary liver cancer: quadrennial review lecture. Dig.Dis.Sci., 9: 133S-46S, 1986.

11. PRINCE, A.M. \& ALCABES, P. The risk of development of hepatocellular carcinoma in hepatitis B virus carriers in New York: a preliminary estimate using death-record matching. Hepatology, 2: 15S-20S, 1982.

12. SAKUMA, D.; TAKAHARA, T.; OKUDA K. Prognosis of the hepatitis virus surface antigen carriers in relation to routine liver function tests: a prospective study. Gastroenterology, 83: 114-7, 1982.
13. SCHAFRITZ, D.A.; SHOUVAL, D.; SHERMAN, H.I.; HADZIYANNIS, S.J.; KEW, M.C. Integration of hepatitis B vinus DNA into genome of liver disease and hepatocellular carcinoma. N.Engl.J.Med, 305: 1067-73, 1981.

14. SILVA, L. Transmissão vertical do virus $B$ da hepatite em Salvador. Bahia, 1984 [Tese de Mestrado Faculdade de Medicina da UFBA].

15. SZMUNESS, W. Hepatocellular carcinoma and the hepatitis B virus: evidence for a causal association. Prog.med Virol., 24: 40-69, 1978.

16. ULRICH, P.P.; BLAT, R.A.; KELLY, I.; BRUNETTO, M.R.; BONDNO, F.; VEJAS, G.N. A precore-defective mutant of hepatitis $B$ virus associated with $e$ antigen-negative chronic liver disease. J.med. Virol., 32: 109-18, 1990.

17. WATERHOUSE, J.; MUIR, C.; CORREA, P. Cancer incidence in five continents. Geneva, World Health Organization, 1977.

18. ZAMAN, S.; MELIA, W.M.; JOHNSON, R.D.; PORTMANN, B.C.; JOHNSON, P.J.; WILLIAMS, $R$ Risk factors for the development of hepatocellular carcinoma in cirthosis: a prospective study in 613 patients. Lancet, 2: 1357-60, 1985.

Recebido para publicação em 25.9.1991 Reapresentado em 3.8.1992 Aprovado para publicação em 4.8 .1992 